\title{
Stay Local, Go Global: A Preliminary Analysis of Chinese-Foreign Higher Education Partnerships in Guangdong, China*
}

\author{
Wong Wei Chin, Yuan Wan, Wang Xun \\ United International College (UIC), Zhuhai, China \\ Yan Siqi \\ London School of Economics and Political Science (LSE), London, England
}

\begin{abstract}
As China moves toward a market system after the "reforms and opening-up" policy since the late 1970s, internationalization is receiving widespread attention at many academic institutions in mainland China. Today, there are 70 Sino-Foreign joint institutions (namely, “Chinese-Foreign Higher Education Partnership”) presently operating within the Chinese nation. Despite the fact that the majority of these joint institutions have been developed since the 1990s, surprisingly little work has been published that addresses its physical distribution in China, and the prospects and challenges faced by the faculty and institutions on an operational level. What are the incentives of adopting both Western and Chinese elements in higher education? How do we ensure the higher education models developed in the West can also work well in mainland China? In order to answer the aforementioned questions, the purpose of this paper is therefore threefold: (a) to navigate the current development of internationalization in China; (b) to compare conventional Chinese curriculum with the "hybrid" Chinese-Foreign education model in present Guangdong province, China; and (c) to delineate the prospects and challenges of developing the internalize Chinese-Foreign higher education in contemporary China.
\end{abstract}

Keywords: internationalization, higher education, Chinese-Foreign higher education institutions, higher education models, universities in Guangdong province, China

\section{Introduction: The Distribution of Chinese-Foreign Higher Education Partnerships in Mainland China}

The Chinese-Foreign Higher Education Partnership-commonly known as “中外高校合作办学” in

\footnotetext{
* Acknowledgement: The former version of this paper was presented at the 9th Future of Education International Conference, Florence, Italy, June 28-29, 2019. This article is part of an ongoing research on the development and practices of internationalization in China. This study was supported by the Education Department of Guangdong Province, China (Grant No. 2018WTSCX193) under the scheme of University Innovation and Enhancement Project.

Wong Wei Chin, Ph.D., assistant professor, Beijing Normal University-Hong Kong Baptist University, United International College (UIC).

Yuan Wan, M.A., teaching assistant, Beijing Normal University-Hong Kong Baptist University, United International College (UIC).

Wang Xun, undergraduate student, Beijing Normal University-Hong Kong Baptist University, United International College (UIC).

Yan Siqi, master student, Department of Sociology, London School of Economics and Political Science (LSE).
} 
Mandarin — has been a popular trend of internationalization in mainland China since the 1990s. Today, there are at least 70 Chinese-Foreign higher education institutions and 1,091 joint-venture undergraduate programs presently operating within 28 Chinese provinces and municipalities in China. Both Jiangsu and Shanghai have established the highest number of internationalized Chinese-Foreign higher education institutions (15.7\%) within China, following by Liaoning (11.4\%), Guangdong (10\%), Shandong (7.1\%), Zhejiang (7.1\%), Chongqing (5.7\%), Sichuan (4.3\%), Beijing (4.3\%), Jilin (4.3\%), Tianjin (2.9\%), Shanxi (1.4\%), Hebei (1.4\%), Hunan (1.4\%), and Hubei (1.4\%), as shown in Figure 1. As of July 11, 2019, China had 2,688 higher education institutions (including all public and private colleges and universities), which means that the numbers of these Chinese-Foreign higher education institutions are equivalent to $2.6 \%$ out of the total of higher education institutions in China today (Ministry of Education [MOE] of the People’s Republic of China, 2019).

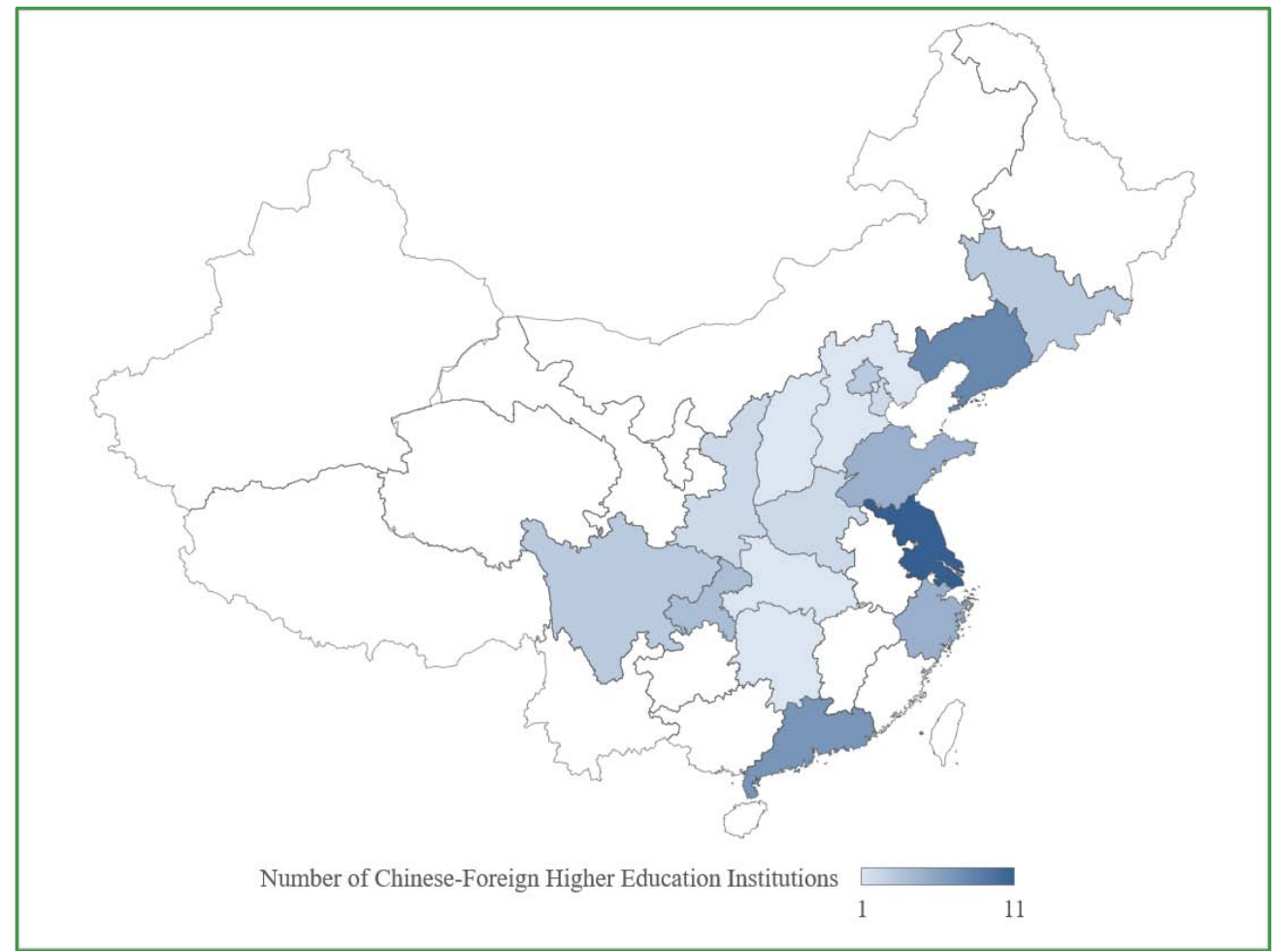

Figure 1. The distribution of Chinese-Foreign higher education partnerships in China, 2019 (Source: Data from the MOE's database, 2019).

Interestingly, there are more than $80 \%$ of undergraduate programs developed not in the first-tier international shipping and trading cities (i.e., Shanghai, Beijing, Shenzhen, and Guangzhou), but in the fast-growing second-tier cities, such as Suzhou and Nanjing in Jiangsu province, Ningbo and Hangzhou in Zhejiang province, and Zhuhai in Guangdong province, etc (as shown in Table 1). In many instances, the majority of these joint institutions and programs are predominated by the Anglo-Saxon countries, which include United Kingdom (29\%) and United States of America (17.4\%); followed by the European countries, such as France (10\%) and Germany (10\%). Despite the Chinese government does not create or publish any official definition for the term "internationalization", this term has been regarded frequently as an expansion of institutional mission through a process of international and intercultural integration into teaching, research, and service functions of the university (Zhang, 2016; Knight, 2003). English-speaking learning environment and 
Western training services are thus being created on Chinese campuses to address opportunities that range from international business to environmental engineering. While some universities have adopted American higher education system by offering a long list of general education courses to encourage critical inquiry and creativity (Beck, 2012, p. 134; Ennew \& Yang, 2009, p. 22).

According to the MOE's database on “Chinese-Foreign Cooperation in Running Schools", the most popular undergraduate subject offered by the present internationalized Chinese-foreign partnerships is engineering (41\%), as shown in Figure 2. This figure also tells us that the second most popular subject is business and management (17.3\%), following by the subject of economics (10.5\%), fashion design (9.6\%), sciences (7\%), art (5\%), medical science (3.5\%), education (2\%), military (1.6\%), law (1.1\%), agriculture (1.1\%), and history $(0.2 \%)$. In some regards, the rapid growth of Chinese internationalization in higher education may relate to the socio-economic development in China and the Chinese parents' preferences and desires to seek greater international learning opportunities for their children without leaving China. What are the incentives of adopting both Western and Chinese elements in higher education? How do we ensure the higher education models developed in the West can also work well in mainland China? In order to answer the aforementioned issues, the following section is written to compare curricula differences between the internationalize Chinese-Foreign higher education model and the conventional Chinese higher education model.

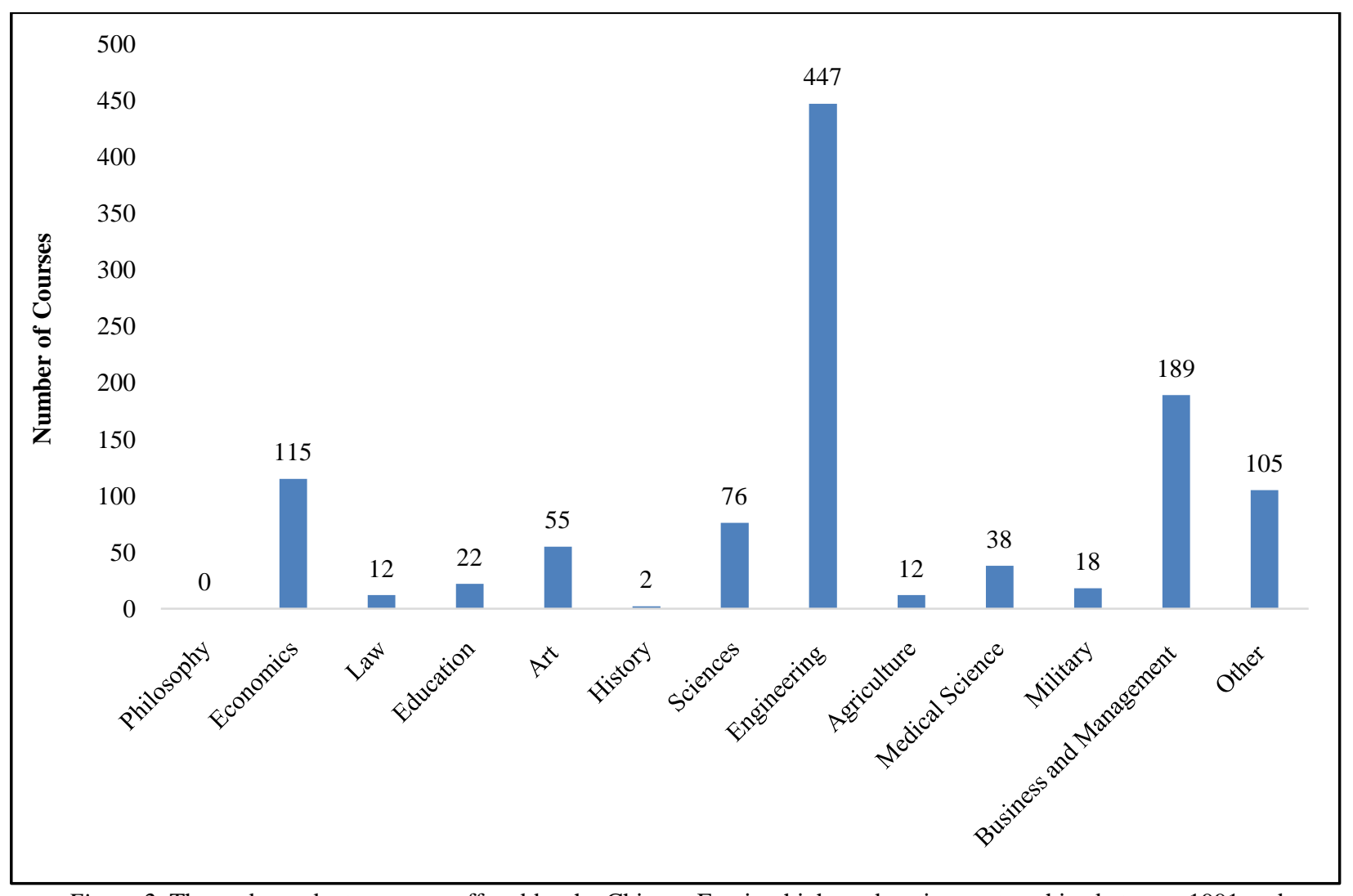

Figure 2. The undergraduate courses offered by the Chinese-Foreign higher education partnerships between 1991 and 2019 (Source: Compiled by authors from the database of MOE). 
Table 1

The Distribution of Chinese-Foreign Higher Education Partnerships in Mainland China, 1991-2019

\begin{tabular}{|c|c|c|c|c|c|}
\hline \multirow{2}{*}{ Locations } & \multicolumn{2}{|c|}{$\begin{array}{c}\text { Jointly established Chinese-Foreign } \\
\text { higher education institutions }\end{array}$} & \multicolumn{2}{|c|}{$\begin{array}{c}\text { Joint venture Chinese-Foreign } \\
\text { undergraduate programs }\end{array}$} & \multirow{2}{*}{$\begin{array}{l}\text { Total of } \\
\text { courses (\%) }\end{array}$} \\
\hline & $\begin{array}{l}\text { Number of } \\
\text { institution(s) }\end{array}$ & $\begin{array}{l}\text { Number of course } \\
\text { offered }\end{array}$ & $\begin{array}{l}\text { Number of } \\
\text { program(s) }\end{array}$ & $\begin{array}{l}\text { Number of } \\
\text { course offered }\end{array}$ & \\
\hline Jiangsu & 11 & 66 & 83 & 83 & 149 (13.7) \\
\hline Shanghai ${ }^{* *}$ & 11 & 39 & 59 & 59 & $98(9.0)$ \\
\hline Shandong & 5 & 22 & 69 & 69 & $91(8.3)$ \\
\hline Henan & 2 & 10 & 79 & 79 & $89(8.2)$ \\
\hline Zhejiang & 5 & 44 & 30 & 30 & $74(6.8)$ \\
\hline Heilongjiang & 0 & 0 & 71 & 71 & 71 (6.5) \\
\hline Jilin & 3 & 22 & 47 & 47 & 69 (6.3) \\
\hline Guangdong & 7 & 46 & 11 & 11 & $57(5.2)$ \\
\hline Hubei & 1 & 3 & 50 & 50 & 53 (4.9) \\
\hline Beijing $^{* *}$ & 3 & 13 & 32 & 32 & $45(4.1)$ \\
\hline Liaoning & 8 & 19 & 25 & 25 & $44(4.0)$ \\
\hline Chongqing ${ }^{* *}$ & 4 & 20 & 16 & 16 & 36 (3.3) \\
\hline Hebei & 1 & 6 & 22 & 22 & $28(2.6)$ \\
\hline Tianjin $^{* *}$ & 2 & 3 & 24 & 24 & $27(2.5)$ \\
\hline Hunan & 1 & 4 & 23 & 23 & $27(2.5)$ \\
\hline Sichuan & 3 & 10 & 12 & 12 & $22(2.0)$ \\
\hline Fujian & 0 & 0 & 17 & 17 & 17 (1.6) \\
\hline Jiangxi & 0 & 0 & 17 & 17 & 17 (1.6) \\
\hline Guangxi & 0 & 0 & 15 & 15 & 15 (1.4) \\
\hline Shaanxi & 2 & 5 & 10 & 10 & 15 (1.4) \\
\hline Anhui & 0 & 0 & 13 & 13 & $13(1.2)$ \\
\hline Yunnan & 0 & 0 & 10 & 10 & $10(0.9)$ \\
\hline Shanxi & 1 & 6 & 2 & 2 & $8(0.8)$ \\
\hline Inner Mongolia & 0 & 0 & 7 & 7 & $7(0.7)$ \\
\hline Guizhou & 0 & 0 & 4 & 4 & $4(0.4)$ \\
\hline Hainan & 0 & 0 & 3 & 3 & $3(0.3)$ \\
\hline Gansu & 0 & 0 & 1 & 1 & $1(0.1)$ \\
\hline Xinjiang & 0 & 0 & 1 & 1 & $1(0.1)$ \\
\hline Total & 70 & 338 & 753 & 753 & $1,091(100)$ \\
\hline
\end{tabular}

Source: Compiled by authors from the database of MOE, People's Republic of China.

Notes. * Data of the following institutions are not included in the MOE's database due to unknown reasons. These institutions include College of Global Talents of Zhuhai's Beijing Institute of Technology (formerly known as “Sino-US College”), The Hopkins-Nanjing Center, National University of Singapore (NUS)-Suzhou Research Institute, Oxford Suzhou Centre for Advanced Research (OSCAR), China Europe International Business School (CEIBS), and Oklahoma City University-Tianjin University of Finance and Economics; ${ }^{* *}$ Four municipalities of the People’s Republic of China; and the remaining locations are Chinese provinces.

\section{Chinese-Foreign vs. Conventional Higher Education Curriculum}

Beijing Normal University-Hong Kong Baptist University, United International College (UIC) is the first liberal arts college established in Guangdong province since 2005. As the first jointly found "hybrid" and "international" higher education institution in Guangdong, English is used as its medium of instruction while the Westernize Hong Kong’s curriculum was imitated to accommodate students’ learning needs within the 
Chinese-speaking context. To better understand the incentives of adopting Chinese-Foreign higher education model in China, we compared the curricula differences between UIC and the Sun Yat-Sen University (SYSU), which is a top-tier conventional Chinese university of Guangdong. In the following section, this paper addresses the recent prospects and challenges faced by the Chinese-Foreign higher education partnerships in contemporary Guangdong province, China.

In analyzing the curricula differences between the "hybrid" Chinese-Foreign higher education model and the conventional school, it is observed that the major differences among these institutions have lied not just in its medium of instruction, but the curriculum structure of credit value and learning modules also has distinct part with regard to the study plan. The recent SYSU's study plan shows that $34 \%$ out of the total credit hours are dedicated to non-major courses. This means that all the students are required to complete at least 33 credits under the category of "Public Compulsory Courses", including two credits in "Chinese Language”, eight credits in "English", four credits in "Physical Education", and 19 more credits in courses related to contemporary Chinese law, military, politics, and cultural ideologies, as shown in the following Table 2.

Table 2

The Structure of Public Compulsory Courses at SYSU, 2018

\begin{tabular}{llll}
\hline Course types & Course titles & Total credits \\
\hline & & College English & 8 \\
& Physical Education & 4 \\
& Moral Character Cultivation and the Basis of Law & 3 & 2 \\
Public compulsory & Contemporary History of China & 6 & 3 \\
courses & Type A & Introduction of Mao Zedong's Thought (Maoism) and the & $2+1$ \\
& & Theoretical System of Socialism with Chinese Characteristics & 2 \\
& & The Principles of Marxism & 2 \\
\hline
\end{tabular}

Source: Compiled by authors from the data of SYSU's study plan of international relations, 2015-cohort.

In addition to compulsory courses, all students are required to complete 16 more credits for the general education courses. Table 3 reveals that there are two sub-divisions of general education courses at SYSU, namely, “Core General Education Course” and "Normal General Education Courses”, of which each student must take six to eight general education courses related to humanities, Chinese classical readings, economics, and entrepreneurship.

Table 3

The Structure of General Education Courses at SYSU, 2018

\begin{tabular}{|c|c|c|c|}
\hline Course types & & Course titles & Credit hours \\
\hline \multirow{5}{*}{$\begin{array}{l}\text { General education } \\
\text { courses }\end{array}$} & \multirow{4}{*}{ Core general education courses } & Chinese civilization & 2 \\
\hline & & $\begin{array}{l}\text { Foundation of humanities and } \\
\text { Reading on classics }\end{array}$ & 2 \\
\hline & & Global perspectives & 2 \\
\hline & & Technology, economics, and society & 2 \\
\hline & Normal general education courses & $\begin{array}{l}\text { Interdisciplinary } \\
\text { Entrepreneurship and innovation }\end{array}$ & 8 \\
\hline
\end{tabular}

Source: Compiled by authors from the data of SYSU's study plan of international relations, 2015-cohort. 
At UIC, however, students are required to complete 72 credits or $55 \%$ out of the total credit hours for their non-major courses, which is about 21\% higher than SYSU. As shown in the following Figures 3 and 4, each student at UIC must complete 48 credit hours or 19 general education courses with respect to English language, music, numeracy, information technology, business, science, foreign languages, history, philosophy, law, government and society, religion, media, physical and emotional health, and whole person education before the graduation. In contrast to SYSU, the Chinese-Foreign higher education institution, i.e., UIC, places greater emphasis on intercultural and global dimension in its curriculum design. Unlike students at SYSU, students at UIC generally have a freedom to choose their free elective courses, while Chinese ideological courses (i.e., Marxism and Maoism) are tentatively not including in the Chinese-Foreign institutional curriculum.

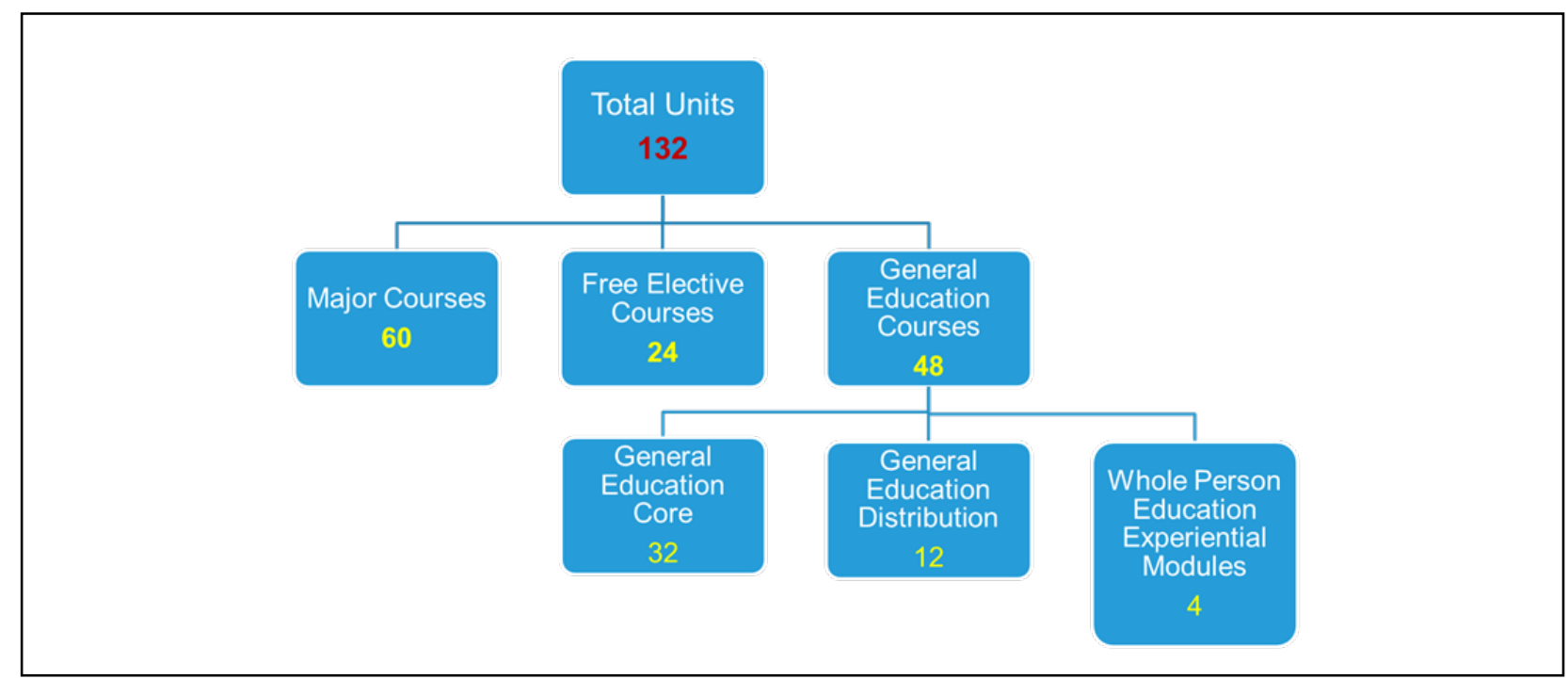

Figure 3. The structure of UIC's undergraduate curriculum (Source: Data from UIC's database).

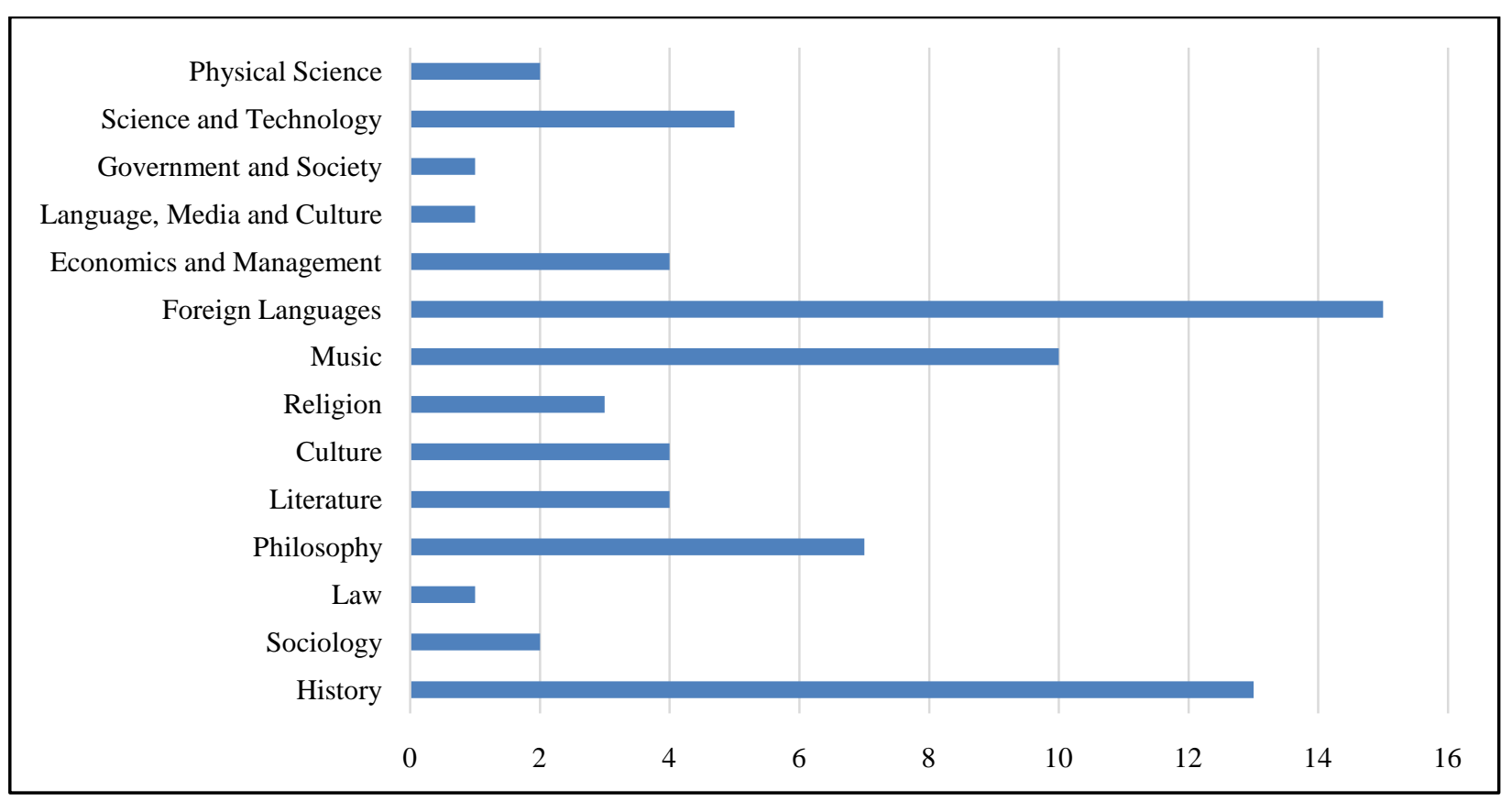

Figure 4. The number of general education courses offered at UIC, 2018 (Source: Data from UIC’s database). 


\section{Recent Prospects and Challenges}

In 2018, there are 249,573 Bachelor's degree holders graduated from 51 universities in Guangdong province (MOE, 2019). Among these universities, 49 of them are the public Chinese universities, while there are only two Chinese-Foreign higher education institutions produced employable graduates for jobs in and outside Guangdong province. The institutions are Beijing Normal University-Hong Kong Baptist University, UIC and the Chinese University of Hong Kong at Shenzhen (CUHK, Shenzhen) ${ }^{1}$. According to a local economic database, the provincial average salaries for a fresh graduate of CUHK, Shenzhen and UIC has been ranked respectively as the Top one and Top six, out of 51 universities within Guangdong province. As shown in the following Table 4, fresh graduates of UIC receive $\$ 11,000$ dollars; while CUHK, Shenzhen (as an institution which having their first generation of fresh graduates since the establishment in 2014) has achieved the highest annual paycheck up to \$20,000 dollars within the Guangdong region.

If we compare the average annual salaries between the two different models, $\$ 8,812$ dollars for fresh graduates from 49 conventional Chinese universities and \$15,571 dollars from two Chinese-Foreign universities, it is apparent that the latter model produces students for better wages in the job market upon their completion. In addition, the annual salary's ranking showing in Table 4 might have reflected the qualities and students' personality characteristics with reference to the education models. Nevertheless, future studies are needed to address the degree to which employers thought about the model of higher education, and which one is better in preparing students for the work situation in and outside Guangdong province.

Table 4

The Average Annual Salary of Fresh Graduates in Guangdong Province, 2018

\begin{tabular}{llll}
\hline Rank & Institution & $\begin{array}{l}\text { Annual salary } \\
(¥)\end{array}$ & Annual salary $^{* *}(\$)$ \\
\hline 1 & The Chinese University of Hong Kong, Shenzhen ${ }^{*}$ & 137,500 & 20,006 \\
2 & SYSU & 103,104 & 15,002 \\
3 & Southern University of Science and Technology & 94,368 & 13,731 \\
4 & South China University of Technology & 88,452 & 12,870 \\
5 & Jinan University & 83,412 & 12,136 \\
6 & Beijing Normal University-Hong Kong Baptist University, UIC & 76,536 & 11,136 \\
7 & Guangzhou Academy of Fine Arts & 75,954 & 11,051 \\
8 & South China Normal University & 75,374 & 10,967 \\
9 & Shenzhen University & 71,268 & 10,369 \\
10 & Guangdong University of Foreign Studies & 69,828 & 10,160 \\
11 & Guangzhou Sport University & 69,552 & 10,120 \\
12 & Xinghai Conservatory of Music & 69,023 & 10,043 \\
13 & Guangzhou University & 68,954 & 10,033 \\
14 & Guangdong University of Finance & 68,328 & 9,942 \\
15 & Guangzhou College of South China University of Technology & 66,859 & 9,728 \\
16 & South China Agricultural University & 65,897 & 9,588 \\
17 & Beijing Normal University, Zhuhai & 65,796 & 9,573 \\
18 & Guangdong University of Education & 65,544 & 9,537 \\
19 & Guangdong University of Technology & 63,828 & 9,287 \\
\hline
\end{tabular}

\footnotetext{
${ }^{1}$ There are seven Chinese-Foreign institutions can be found in Guangdong province today. The other five institutions, however, are all newly established Chinese-Foreign universities since 2015, and the first-generation of undergraduates are still completing their bachelor's degree studies.
} 
(Table 4 to be continued)

\begin{tabular}{|c|c|c|c|}
\hline 20 & Guangdong Pharmaceutical University & 63,612 & 9,256 \\
\hline 21 & Shantou University & 62,220 & 9,053 \\
\hline 22 & Zhuhai College of Jilin University & 60,742 & 8,838 \\
\hline 23 & Beijing Institute of Technology, Zhuhai & 60,036 & 8,735 \\
\hline 24 & Foshan University & 59,856 & 8,709 \\
\hline 25 & Jiaying University & 59,376 & 8,639 \\
\hline 26 & Guangzhou Medical University & 58,944 & 8,576 \\
\hline 27 & $\begin{array}{l}\text { University of Electronic Science and Technology of China, } \\
\text { Zhongshan Institute }\end{array}$ & 57,668 & 8,391 \\
\hline 28 & Dongguan University of Technology & 57,608 & 8,382 \\
\hline 29 & Shaoguan University & 57,540 & 8,372 \\
\hline 30 & Guangzhou University of Chinese Medicine & 56,571 & 8,231 \\
\hline 31 & Lingnan Normal University & 56,170 & 8,173 \\
\hline 32 & City College of Dongguan University of Technology & 54,598 & 7,944 \\
\hline 33 & Zhongkai University of Agriculture and Engineering & 54,587 & 7,942 \\
\hline 34 & Neusoft Institute Guangdong & 54,337 & 7,906 \\
\hline 35 & Huali College Guangdong University of Technology & 54,324 & 7,904 \\
\hline 36 & Huizhou University & 53,724 & 7,817 \\
\hline 37 & Xinhua College of SYSU & 53,208 & 7,742 \\
\hline 38 & Zhaoqing University & 52,848 & 7,689 \\
\hline 39 & Southern Medical University & 52,836 & 7,688 \\
\hline 40 & Guangdong Peizheng College & 50,796 & 7,391 \\
\hline 41 & Guangdong University of Petrochemical Technology & 50,751 & 7,384 \\
\hline 42 & Wuyi University & 49,368 & 7,183 \\
\hline 43 & Guangdong University of Science and Technology & 49,044 & 7,136 \\
\hline 44 & Guangzhou College of Commerce & 48,480 & 7,054 \\
\hline 45 & Hanshan Normal University & 47,916 & 6,972 \\
\hline 46 & Guangdong Ocean University Cunjin College & 47,532 & 6,916 \\
\hline 47 & Huashang College, Guangdong University of Finance \& Economics & 46,656 & 6,788 \\
\hline 48 & Nanfang College of SYSU & 44,724 & 6,507 \\
\hline 49 & Zhujiang College of South China Agricultural University & 43,824 & 6,376 \\
\hline 50 & Guangdong Baiyun University & 43,500 & 6,329 \\
\hline 51 & Guangdong Polytechnic College & 38,568 & 5,612 \\
\hline
\end{tabular}

Source: Data compiled by authors from http://21jingji.com, literally “economic network of the 21st century”.

Notes. * Chinese-Foreign higher education institution; ${ }^{* *}$ The average annual salaries in CNY were converted to USD according to the international exchange rate 1: 0.1455 on July 12, 2019.

Graduates from Chinese-Foreign universities also show higher motivations to attain postgraduate education outside China. Table 5 indicates that among 51 universities in Guangdong, UIC has ranked as the first in 2018 for having the highest percentage of graduates that go on further their studies in the overseas countries. Particularly, overseas countries, such as United Kingdom, United States, Canada, Australia, and Singapore reign as the most popular study abroad destinations; and some graduates go on pursue their master's degree in universities located in Hong Kong (Special Administrative Region of China). Graduates from UIC comprise the largest proportions of study abroad in 2018 (68\%), while among the students graduated from the conventional Chinese universities their percentage of further education is $13 \%$ in average. In this light, it is clear that the Chinese-Foreign higher education model may provide local Chinese students a better chance to further their postgraduate studies abroad after acquiring international academic trainings and English speaking skills in China. 
Table 5

The Best Ranking Universities in Further Education in Guangdong, 2018

\begin{tabular}{lll}
\hline Rank & Institutions & Percentage (\%) \\
\hline 1 & Beijing Normal University-Hong Kong Baptist University, UIC & 68 \\
2 & Southern University of Science and Technology & 33 \\
3 & SYSU & 18 \\
4 & Guangdong University of Foreign Studies & 15 \\
5 & Jinan University & 14 \\
6 & South China University of Technology & 12 \\
7 & Shenzhen University & 12 \\
8 & South China Normal University & 6 \\
9 & Shantou University & 5 \\
10 & Guangzhou Academy of Fine Arts & 5 \\
\hline
\end{tabular}

Source: Compiled by authors from the official website of each institution.

Despite the prospective chances for getting better salary and postgraduate learning opportunities, many of the Chinese-Foreign higher education partnerships are facing diverse challenges in mainland China. According to the standard measurement of Higher Education Act and Measures on China-Foreign Higher Education Partnerships, China's MOE has conducted three major terminations since 2010. The latest termination was adopted in June 2018, of which 229 joint-venture Chinese-Foreign undergraduate programs and four Chinese-Foreign higher education institutions had been terminated in perpetuity due to the following reasons: (a) poor quality in teaching; (b) skyrocketing fees; and (c) poor teaching outcomes, such as low rate of job employment and fail to attain further education opportunities among the graduates (Redden, 2018). Table 6 reveals the name and location of the terminated Chinese-Foreign universities in 2018.

Table 6

List of Terminated Chinese-Foreign Higher Education Institutions since June 2018

\begin{tabular}{|l|l|l|l|}
\hline Locations & Institutions & Partnership & Year of establishment \\
\hline Langfang City, Hebei Province & $\begin{array}{l}\text { University of International Business and Economics, } \\
\text { Fort Hays State University }\end{array}$ & USA & 2001 \\
\hline $\begin{array}{l}\text { Qinhuangdao City, Hebei } \\
\text { Province }\end{array}$ & $\begin{array}{l}\text { Hebei Normal University of Science \& Technology, } \\
\text { Medicine Hat College }\end{array}$ & Canada & 2002 \\
\hline Xi'an City, Shaanxi Province & $\begin{array}{l}\text { XJTU-HKUST Joint School of Sustainable } \\
\text { Development at Xi'an Jiaotong University }\end{array}$ & Hong Kong & 2014 \\
\hline Taiyuan City, Shanxi Province & $\begin{array}{l}\text { Shanxi Agricultural University-Anhalt University of } \\
\text { Applied Sciences }\end{array}$ & Germany & 2002 \\
\hline
\end{tabular}

Source: Compiled by authors from the MOE's database.

Figure 5 indicates that there are 160 Chinese-Foreign undergraduate programs or $70 \%$ out of the total termination are located in northern China, while 74 or 32\% of undergraduate programs had ceased in operation in southern China in June 2018. In Guangdong province, there were four joint venture Chinese-Foreign undergraduate programs had been terminated, including the "Program on Economics and Finance" organized by Peking University-Hong Kong University, "Program on International Accounting Business” organized by Guangzhou University-James Cook University of Australia, "Program on International Trade” by SYSU-Jean Moulin University Lyon 3, and the "Program on Senior Management, Logistics and Supply Management” by Tsinghua University-Chinese University of Hong Kong. Interestingly, these terminated programs were business 
and economic-oriented subjects, and these are the subjects being accused of cooperating with diploma mills since the first termination in 2010 (Wang, 2018).

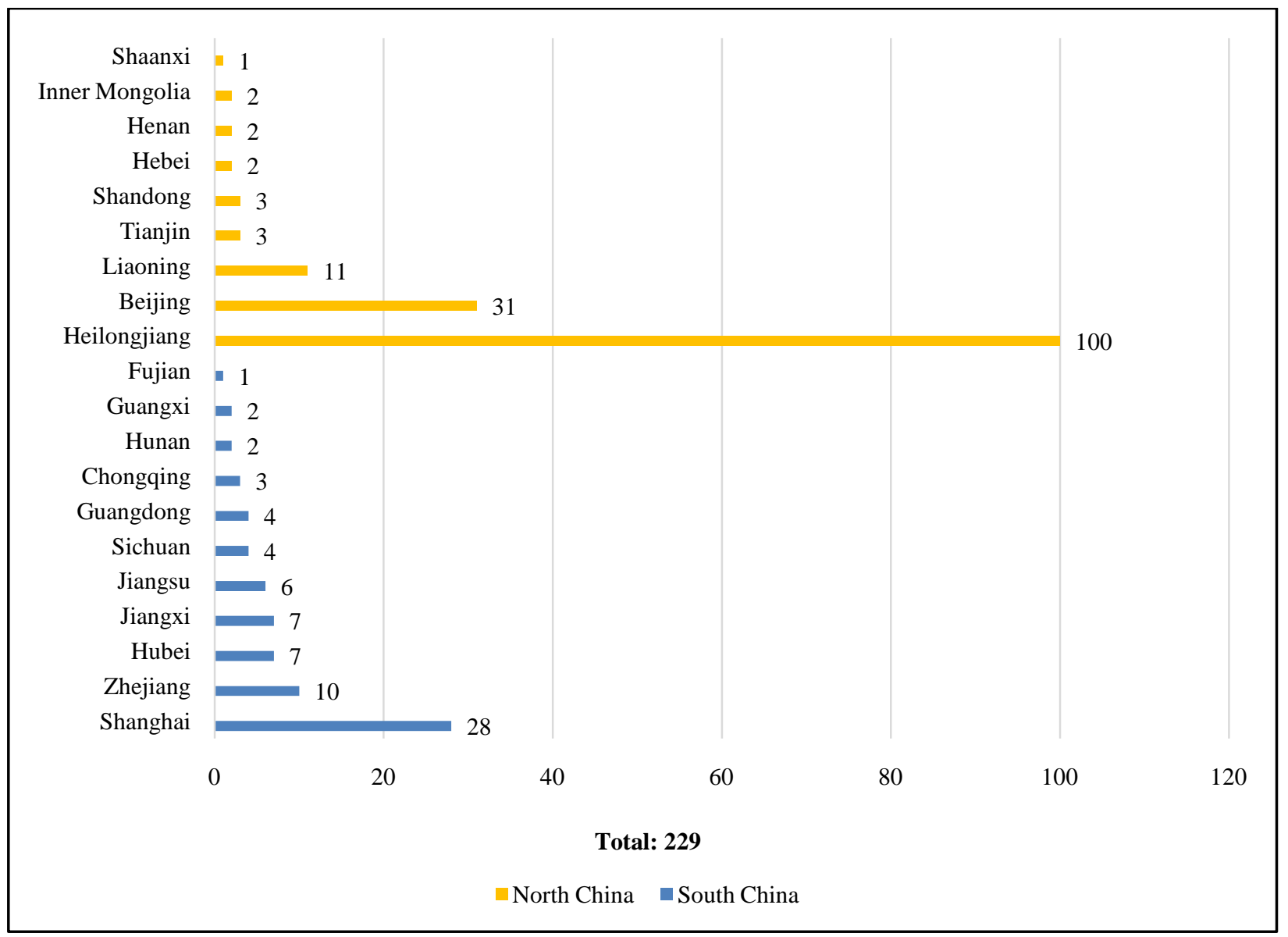

Figure 5. The number of terminated China-Foreign undergraduate programs in mainland China, 2018 (Source: Compiled by authors from the MOE's database).

Note. The northern and southern part of China is usually determined based on the Qinling Huaihe Line $34^{\circ} \mathrm{N}$.

\section{Concluding Remarks}

The numbers of Chinese-Foreign undergraduate programs, colleges, and universities have greatly increased across many provinces in mainland China over the past two decades. This implies that in China there has been a growing importance of English as the medium of distribution and instruction of knowledge in the internationalization of curricula in higher education institutions. Although the graduates from these internationalize Chinese-Foreign universities are more likely to attain better wages and postgraduate learning opportunities in the overseas countries, but the driving forces behind the development of Chinese-Foreign higher education partnerships lies not only in such incentives. The regular terminations towards the Chinese-Foreign higher education partnerships clearly indicate that there are pressing problems within the "hybrid" Chinese-Foreign education model, and the terminations also evoke Chinese-Foreign higher education partnerships should avoid diploma mills but carry out quality teaching strategies to make notable shifts in student performance. Meanwhile, further research and pedagogical studies are also necessary to address advantages of covering both multi-linguistic and intercultural dimension in higher education institution, and 
how well it can be a mechanism for facilitating the internationalization and quality teaching of the higher education system in China.

\section{References}

Beck, K. (2012). Globalizations: Reproduction and resistance in the internationalization of higher education. Revue comedienne de I'éducation, 35(3), 133-148.

Ennew, C., \& Yang, F. (2009). Foreign universities in China: A case study. European Journal of Education, 44(1), 21-36.

Knight, J. (2003). Updating the definition of internationalization. International Higher Education, 33, 2-3.

Ministry of Education (MOE) of the People's Republic of China. (2019). Official database of the Ministry of Education of the People's Republic of China on the regulations and Chinese-Foreign cooperation in running schools. Retrieved from http://en.moe.gov.cn/

Redden, E. (2018). Closures of China-Foreign programs: Inside higher education. Retrieved from https://www.insidehighered.com/news/2018/07/11/chinas-ministry-education-approves-termination-more-200-chinese-f oreign-cooperative

United International College (UIC), Beijing Normal University-Hong Kong Baptist University’s Database. (2019). Study Plan. Retrieved fromhttps://www.uic.edu.hk//en/

Wong, W. C., Yan, S., \& Yuan W. (2019). Internationalization of higher education in mainland China: A preliminary analysis of higher education models in Guangdong province. In Conference Proceedings of the Future of Education 2019. Italy: Filodiritto Editore.

Wang, Y. (2018). Government shuts over 200 Chinese-Foreign education partnerships. In Sixth Tone. Retrieved fromhttp://www.sixthtone.com/news/1002570/government-shuts-over-200-chinese-foreign-education-partnerships

Zhang, R. (2016). Brief analysis on the major revolution of the Sino-Foreign higher education collaborative model. World Educational Information, 1, 57-62. 